\title{
NON-MONETARY ASSESSMENT AND MAPPING OF THE POTENTIAL OF AGROECOSYSTEM SERVICES IN RURAL SLOVAKIA
}

\author{
Jarmila Makovníková, Boris Pálka ${ }^{1}$, \\ Stanislav Kološta, Filip Flaška, Katarína Orságová, Mária Spišiaková
}

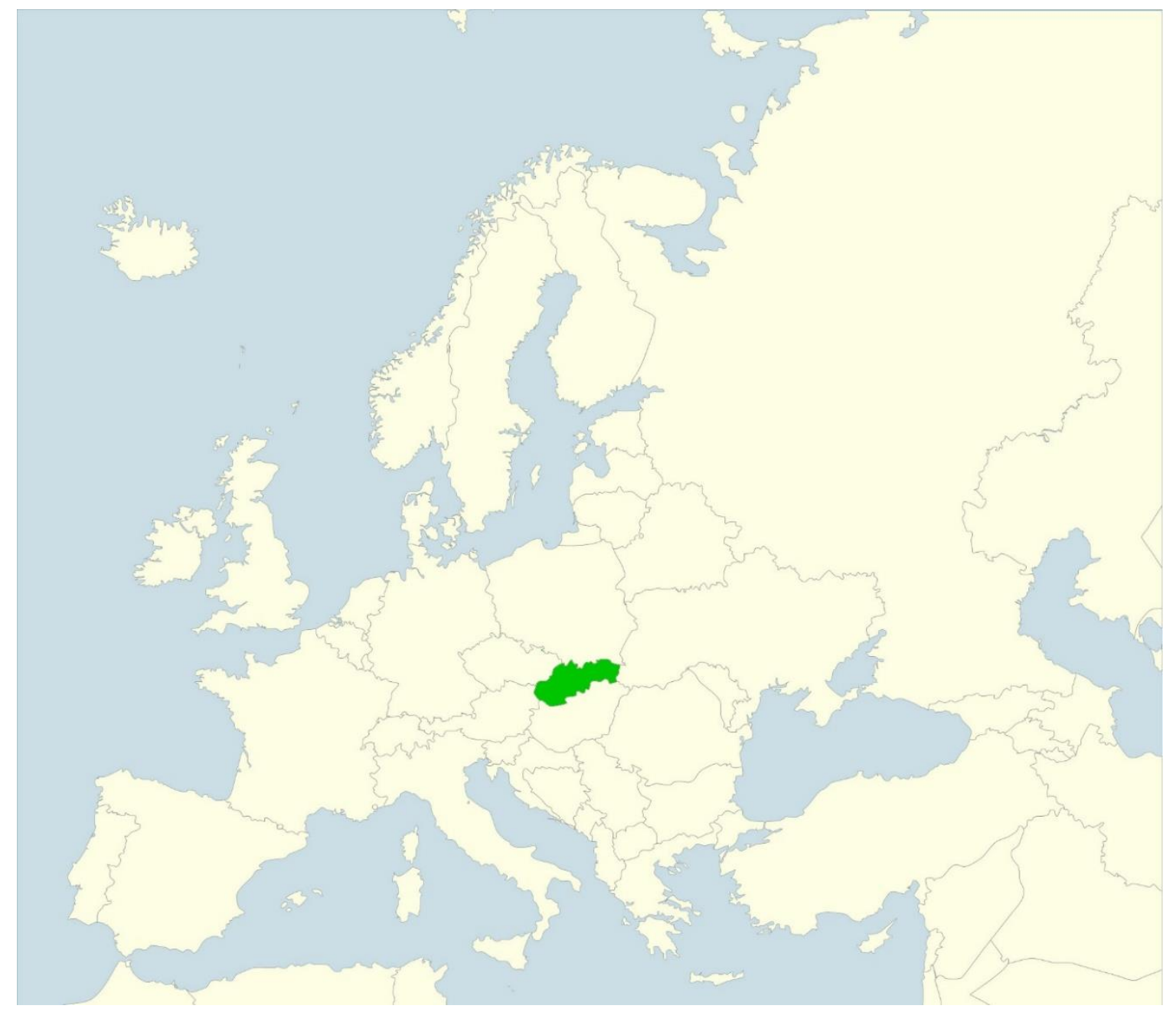

\footnotetext{
1 RNDr. Jarmila Makovníková, CSc., ORCID 0000-0002-3328-405X, e-mail jarmila.makovnikova@nppc.sk; RNDr. Boris Pálka, Ph.D., ORCID 0000-0003-4104-7406, e-mail: boris.palka@nppc.sk, National Agricultural and Food Centre/ Soil Science and Conservation Research Institute Bratislava, Slovakia

2 Ing. Stanislav Kološta, Ph.D., ORCID: 0000-0003-1501-9532, e-mail: stanislav.kolosta@umb.sk, Ing. Filip Flaška, Ph.D., e-mail: filip.flaska@umb.sk; Ing. Katarína Orságová, Ph.D., e-mail: katarina.orsagova@umb.sk; Ass. Prof. Mgr. Mária Spišiaková, Ph.D., e-mail: maria.spisiakova@umb.sk, Faculty of Economics, Matej Bel University Banská Bystrica, Slovakia
} 
Abstract: The updated Slovak National Biodiversity Strategy to 2020 is a key document in the field of biodiversity protection, and assessment together with mapping of the value of different ecosystem services is one of its most important objectives. This study applies the first non-monetary assessment and pilot mapping of agroecosystem services in the Slovak Republic at seven model sites located in the main climatic areas and estimates the agroecosystem services potential of Slovakia as a rural country with a transformed multi-criteria approach used at national level. It suggests that the distribution of the value of agroecosystem services is geographically different probably due to climatic conditions, slope and soil texture. Our assessment provides a suitable basis for further investigation of agroecosystem services and contributes to optimizing sustainable land use management in Slovakia.

Key words: ecosystem services, agroecosystem services, assessment, mapping

Abstrakt: Aktualizovaná národná stratégia pre biodiverzitu Slovenska do roku 2020 je klúčovým dokumentom $v$ oblasti ochrany biodiverzity, pričom vyhodnocovanie a mapovanie hodnoty rôznych ekosystémových služieb je jedným z jej najdôležitejších ciel'ov. Táto štúdia aplikuje prvé nepeňažné hodnotenie a pilotné mapovanie agroekosystémových služieb $\mathrm{v}$ Slovenskej republike, ktoré bolo testované na siedmich modelových lokalitách nachádzajúcich sa $\mathrm{v}$ hlavných klimatických oblastiach; použitý multikriteriálny prístup bol na národnej úrovni transformovaný na odhad potenciálu agroekosystémových služieb pre Slovensko ako vidiecku krajinu. Táto štúdia naznačuje, že rozdielne hodnoty agroekosystémových služieb sú geograficky odlišné pravdepodobne z dôvodu rôznych klimatických podmienok, sklonu a textúry pôdy. Naše hodnotenie poskytuje vhodný základ pre d’alšie skúmanie agroekosystémových služieb a prispieva k optimalizácii trvalo udržatel'ného manažmentu využívania pôdy na Slovensku.

Kl'účové slová: ekosystémové služby, agroekosystémové služby, vyhodnocovanie, mapovanie

\section{Introduction}

The European Union's Biodiversity Strategy to 2020 is aimed at stopping or reversing the loss of biodiversity and the degradation of ecosystem services as well as building a resourceefficient and green economy towards reduction of global biodiversity loss. Especially the EU initiative Biodiversity for Life pays attention to the strong linkages between ecosystems and livelihoods with a strong focus on sustainable management of natural resources, ecosystem conservation for food security and sustainable rural development, and ecosystem-based solutions towards a green economy.

Agricultural ecosystems, covering between $28 \%$ and $37 \%$ of the global land area (Plieninger et al., 2012), are necessary for supplying goods and services to human society (MEA, 2005). The main ecosystems in Europe are considered forest and woodland (41\% of the territory), cropland (25\% of the territory), and grassland (19\% of the territory) (Eurostat, LUCAS 2012 survey). Agricultural land covers almost half of the EU's area, of which approximately $2 / 3$ is used for arable crops, almost $1 / 3$ for permanent grassland and meadows, and the rest for permanent crops (EC, 2015). Achieving good levels of agricultural productivity in biodiverse systems will be important in the economic development of rural areas (Bullock et al., 2006). Agriculture is an important factor forming the European rural countryside and influencing its ecosystem services of green infrastructure (Kurz, 2018; Kušar, 2019), and agricultural production is necessary for human well-being. In an effort to reach the Biodiversity Strategy 2020 targets, the EU needs fertile soil, clean water and a healthy level of biodiversity, agroecosystems not excluded. 
Agricultural management practices can have a substantial positive impact on the conservation of the EU's wild flora and fauna. The inclusion of landscape elements in arable land ecosystems, according to the methodological guideline of the Ministry of Industry and Trade of the Slovak Republic (Methodical guideline of the Ministry of Industry and Trade No. 1304/2010630), is an important act to increase the biodiversity of agroecosystems of arable soils. In spite of the fact that the value of agriculture is enormous (Power, 2010), and ecosystem services have been paid attention in the recent time, there are only few studies on the biodiversity of agroecosystems and its impact on crop yields (Garbach et al., 2014). Therefore, decision makers and planners at national, regional and local level can benefit from the knowledge about the value of agroecosystem services on the managed territories.

More than $40 \%$ of the territory of the Slovak Republic are forests, $49.16 \%$ is agricultural land, $1.93 \%$ water bodies, and non-agricultural and non-forest land is $9.8 \%$. Over $23 \%(1,142,151 \mathrm{ha})$ of the territory are protected areas, including protection zones, but only $16 \%$ of species and $29 \%$ of habitats are in a favorable conservation status, and the other biotopes are either in an unfavorable or unknown status. In December 2013, the Ministry of Environment of the Slovak Republic updated the National Biodiversity Strategy to 2020, where 2 of 9 priorities are directly focused on preservation and enhancement of ecosystems and their services, and on an agricultural policy favorable to biodiversity in all agriculturally utilized areas. The assessment of ecosystems and their services is essential to align state policies with biodiversity conservation objectives and to make decisions on efficient use of natural resources and support the development of society's well-being. The Slovak National Biodiversity Strategy aims to assess and map ecosystem services in general, and in particular, the ecosystem services provided by agriculture land, which creates a substantial part of the Slovak territory. At the same time, countryside has a great socio-economic value and contributes to fulfilling the objectives of the Slovak Rural Development Program (SNBS, 2013). So far, Slovakia has not had suitable tools for detailed modeling and assessment of agroecosystem services at national or regional level. The assessment of ecosystem services is best developed for forestry and nature conservation areas (Mederly et al., 2019). Following the national assessment and mapping initiatives in the EU and Slovakia, the aim of this study is to make a non-monetary assessment and create a pilot map of agroecosystem services in the Slovak Republic at seven model sites located in the main climatic areas and estimate the agroecosystem services potential of Slovakia as a rural country by a transformed multi-criteria approach used at national level.

In the following parts of the paper we will give a theoretical background of ecosystem services and their valuation (Section 2), explain the methods used and describe the studied locations and data sources (Section 3), discuss our findings (Section 4), and at last, we will make concluding remarks (Section 5).

\section{Theoretical background}

Ecosystem services (provisioning, regulating and cultural) are basically determined by the interaction between ecological and social systems, because only the ecosystem processes contributing to the satisfaction of human needs can be defined as ecosystem services (Birkhofer et al., 2015). Service-providing ecosystems are referred to as natural capital (Constanza and Daly, 1992). On the basis of this, natural capital could be perceived as the linkage between the economy and ecological dimensions. In a sustainable perspective, natural capital has to be related to other forms of capital, such as production capital, human capital and social or cultural capital. Explicit quantification and mapping of ecosystem services is also considered to be one of the main requirements to implement the concept of ecosystem services into institutional decision-making. One of the basic production factors is land and the research of agroecosystem services helps to understand the sustainable use of land.

A transparent and explicit assessment of ecosystem services and their benefits is important in the process of democratic decision-making (Constanza et al., 2017). Often, the studies focus on landscape and land use, mapping and modeling of the changes of specific ecosystem services or their combination, either as a single case study (Schirpke et al., 2013; Bürgi et al., 
2014) or as development at a single point in time (Lamarque et al., 2011; Grêt-Regamey et al., 2014; Crouzat et al., 2015). The models and their map presentations should reflect biophysical factors on the one hand, but on the other hand, they should be applicable in decision-making of administrative units (Burkhard et al., 2013).

Most of the spatially explicit policy support systems are now web-based (ARIES, InVEST), however, their methodological approaches significantly vary. Availability of data as well as mapping of distribution are a critical factor that determines which decision support systems are suitable for data scarce regions (Pandeya et al., 2016). Despite the consensus around the general merit of accounting for ecosystem services, a systematic guidance on what and how to measure is lacking (Olander et al., 2018). Assessment and mapping of ecosystem services should contribute to the overall picture of the societal value of nature (Costanza et al., 2014).

The rural society and the regional economy benefit from agricultural land when production fulfills a demand. These benefits can be quantified by their monetary or non-monetary value. Despite some efforts to estimate the value by monetary methods, most policy support systems use nonmonetary valuation approaches (Pandeya et al., 2016). Different ecosystem services need different approaches to their assessment (Vačkár et al., 2013). Agro-ecosystem services can be valued by the contingent valuation method, the hedonic valuation method and the travel cost method. The value of ecosystem services depends on both the capacity of the land to deliver services and on the socio-economic context (Termorshuizen et al., 2009; Burkhard et al., 2012), as well as on the needs and preferences of stakeholders that are affected by these services (Hein et al., 2006). The agricultural sector is often a producer and a beneficiary of the provisioning services and the regulating and supporting services that enable agricultural production through nutrient cycling and pollination (Zhang et al., 2007). In the case of cultural ecosystem services, it is mainly the local community and tourism industry who benefits, rather than the landscape managers themselves (Zanten et al., 2014). For these reasons, agricultural policy became landscape policy, which defines multifunctional agriculture as a provider of many ecosystem services (Krammer \& Rohrmoser, 2012).

Monetary valuation of ecosystem services is based on quantification of the importance of ecosystems towards human well-being in connection with economic prosperity. European countries should assess the monetary value of ecosystem services and implement them into accounting and reporting systems at EU and national level (Maes et al., 2011). Many studies directly sum up all the monetary ecosystem services value to obtain the total value despite the fact that one ecological process can support more than one ecosystem services (as coproducts), which results in double accounting, but cannot be considered a proper method to value the supporting services, such as biodiversity and climate regulation (Yang et al., 2018). Monetary methods are not sufficient to measure the full scope of the benefits people can have from ecosystem services (Costanza et al., 2017). Non-monetary valuation methods are suitable for elimination/reduction of market failures and are increasingly being used to assess the value of various ecosystem services (Randall, 2007).

To understand the ecosystems values, such as provisioning services, regulating services, landscape beauty, and cultural heritage, we need a robust non-monetary valuation method which can address specific contexts at local level. Non-monetary valuation expresses an explicit distinction from the valuation methods as it designates the importance of natural capital and ecosystem services, expressed by people towards nature (Gomez-Sal et al., 2003; de Groot et al., 2010; Chan et al., 2012). Non-monetary assessment can be used at different levels of ecosystem management, planning and decision making. It investigates the values of ecosystems through a wide range of quantitative and qualitative measures other than money (Chan et al., 2012), because not every ecosystem service can be assessed in measurable units. A more comprehensive approach to the valuation of agroecosystem services is provided by expert methods based on a combination of ecological benefits and costs of revitalization of the relevant habitats, for example the Hessen method, the Biotope Valuation Method (BVM) (Seják et al., 2003) and the Energy-Water-Vegetation method (Seják et al., 2010). However, they are not always suitable for the assessment and evaluation of agroecosystems of arable land and intensively used grassland due to lack of input parameters in existing databases for agroecosystems. Another way is to use qualitative assessment in combination with a choice 
model to rank and value the most important functions of the current agroecosystems (Faccioni et al., 2019). For many ecosystems, the actual ecosystem service performance can only be estimated by using modeled and averaged values and datasets. Data availability and complexity is the limiting factor for the quality and content of produced indicators.

Economic evaluation of ecosystem services in Slovakia is relatively underdeveloped. There have been several activities in this area, for example, the evaluation of ecosystem services in Slovak national parks was researched by Füzyová et al. (2009), Getzner (2010), Považan (2011), Švajda \& Fenichel (2011), Považan (2013), the evaluation of production capacity of soils by Džatko (2002), or water by Bujnovský et al. (2011). Yet, a comprehensive monetary assessment of ecosystem services is still absent, not to mention the research gap across all fields of non-monetary assessment of ecosystem services despite the indisputable advantages of this type of assessement.

\section{Material and method}

\subsection{Method of assessment and mapping of agroecosystem service potential}

For the design of agroecosystem services assessment, we chose a non-monetary model whose modification was tested at model locations with respect to the possibilities of databases and input parameters. The assessment methods of agroecosystem services are described in detail in a study by Makovníková et al. (2018). The potential of individual ecosystem services is assessed on the basis of natural environment parameters and land use factors. Some authors use biophysical, spatially quantified data for this purpose (Seják et al., 2010; Alam et al., 2016). In our assessment, we used the results and maps of the potential of agroecosystem services, with ecosystem functions as a basis (Makovníková et al., 2017). We took an agro-eco principle (Girardina, Colmara in Girardin et al., 1999), whose aim is to describe and characterize the relationship between agriculture and the environment by indicators that determine ecosystem processes and functions. We assessed individual indicators of agroecosystem services with an expert scoring system, which is a frequent assessment tool of complex natural systems (MEA, 2005; Lovell et al., 2010; Frélichová, Fanta, 2015). The assessment matrix was created from combinations of agro-ecological indicators (inclination of the relief, climatic units, soil texture and land type) according to the proposed assessment system as follows:

1. Climatic region (categories: moderately cold, moderately warm, warm and very warm (Kizeková et al., 2018),

2. Slope topography (categories: $0-2^{\circ}, 2.1^{\circ}-5^{\circ}, 5.1^{\circ}-12^{\circ}$ and more than $12^{\circ}$ ),

3. Soil texture (categories: soil particles $<0.01 \mathrm{~mm}$ less than $20 \%, 20-45 \%$, more than $45 \%$ ) and

4. Land use (arable land, grassland).

By combining these agro-ecological indicators, we divided the agroecosystem layer into 100 different subcategories which allowed us to assess this particular ecosystem more accurately; each of the subcategories is a combination of the agro-ecological indicators mentioned. In other words, we divided the total layer of agricultural land on the basis of possible combinations of the above mentioned agro-ecological indicators into 100 subcategories and each of these subcategories has its ecosystem service value based on the evaluated soil parameters.

Within the Corine Land Cover (CLC, database 2012 year) layer, which is the primary input into ecosystem services assessment models, the agroecosystem is divided into arable land and grassland (Maes, 2018), which does not allow to make an explicit spatial assessment of the potential of their agroecosystem services. For the purposes of ecosystem assessment in the Czech Republic, for example, a consolidated layer of ecosystems has been created, which distinguishes artificial (anthropogenically affected) surfaces and natural habitat types (Vačkár et al., 2013). Agroecosystems of arable land, however, represent only one separate category, so all ecosystem services of arable land in the country are evaluated equally, regardless of their location, biophysical conditions, and management. 
The input database of non-monetary assessment was the result of expert scoring evaluation of the potential of individual agroecosystem services which was rated within categories from 1 (very low potential) to 5 (very high potential) (described in detail in the study Makovníková et al., 2018). The assessments are designed to aggregate values for the two main groups of agroecosystem services, namely provisioning and regulating services, ranging from 0 to 100 of non-monetary units. 0 means the minimum and 100 the maximum level of a given group of agro-ecosystem services of the assessed ecosystem. In the group of regulating services (with the same overall maximum value as the provisioning services group), four services are evaluated, namely water regime regulation, soil erosion regulation, soil pollution regulation (immobilization of hazardous substances) and climate regulation (carbon accumulation in soil). Individual regulating services are evaluated on the basis of input indicators (Makovníková et al., 2019) in five categories (very low potential 1 to very high potential 5), each category having a value of 5 non-monetary units, and the maximum value of a single regulating service is 25 units. For the cultural services group, i.e. summer recreational activities, winter recreational activities and year-round recreational activities (for which agroecosystems also have a potential to perform, but their real use is lower for agricultural land; Burkhard et al., 2009), we used nonmonetary valuation according to their potential proposed by Makovníková et al. (2016) - with the range of 10 to 50 units (very low potential 1 to very high potential 5 , each category having a value of 10 non-monetary units). Thus, the maximum total value of agroecosystem services can reach 250 non-monetary units. The assessment system was verified on pilot sites located in different soil-ecological regions of Slovakia (Scheme 1).

Non-monetary pilot assessment of the land capacity for the provision of agro-ecosystem services was carried out on the basis of three main input indicators (three groups of agroecosystem services) and four supplementary indicators (agro-ecological indicators - slope of the relief, climatic units, soil texture and land type), which made it possible to create the capacity value map of the agroecosystem services of the landscape. To obtain assessment results and mappings which can be compared spatially among each other, all indicators produced were aggregated into a $100 \mathrm{~m}$ x $100 \mathrm{~m}$ grid for consistency. The values defined represent the most suitable indicator characteristics derived from the used data.

The resulting values were converted into spatial units of $100 \times 100 \mathrm{~m}$ with a uniform scale of 0 250 , where 0 represents the lowest value of the country's capacity to provide agroecosystem services, and 250 theoretically the highest possible value of the capacity. By creating these spatial units, we achieved an interconnection of natural units with administrative units (NUTS), which is a new approach within Slovakia. We used ESRI's software package ArcGIS for Desktop Advanced version 10.3. The designed units are compatible with the spatial units (arable land, grassland) in the international database (Corine Land Cover), which carries information on the use of land. We calculated a weighted average of the non-monetary value of each agroecosystem service within each mapping unit for the territory of the Slovak Republic. The resulting capacity of the country is not expressed in biophysical or monetary values, but in a relative non-monetary value. Minimum and maximum values can be replaced by specific biophysical units or monetary values based on specialized research or value (benefit) transfer method from known valuation studies of a given ecosystem service (Mederly et al., 2019). 
Scheme 1. Categories of potential of agroecosystem services with non-monetary assessment.

Agroecosystem services potential

non-monetary units

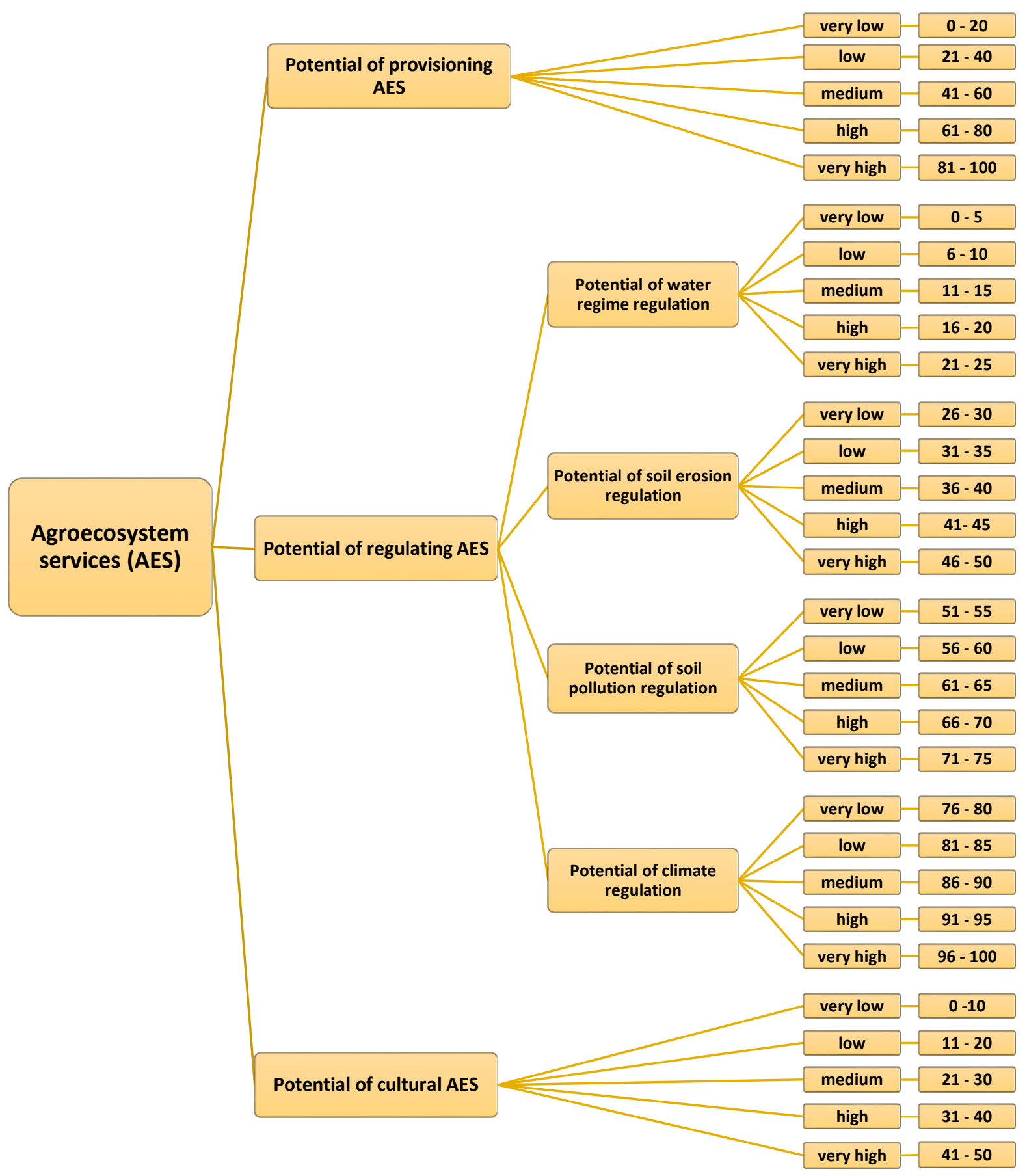




\subsection{Study sites}

For the analysis of non-monetary agroecosystem services valuation, our model study sites are located in the main climatic areas (Džatko, 2002, Kizeková et al., 2018) of Slovakia (Figure 1). Localities Stráňany (ST), Zeleneč (ZE) and Závod (ZA) are in the very warm climatic area, locality Medovarce (ME) is in the warm climatic area, localities Čoltovo (CO) and Tajov (TA) are in the moderately climatic area and locality Vikartovce (VI) is in the cold climatic area of Slovakia. Soil quality at model sites varies and decreases in this order: ZE (Chernozem) > ST (Fluvisol) > ME (Fluvisol) > CO (Cambisol) > ZA (Regosol) >TA (Cambisol) >VI (Rendzina). Each site was analyzed for two types of land - arable land with annual plants and permanent grassland, and a model of agroecosystem services was constructed for each site. The model localities are located in various climatic areas and represent the main soil ecosystems of the Slovak Republic. We tested the proposed methodology for non-monetary assessment of agroecosystem services at model localities, and subsequently we used this methodology for the first non-monetary assessment of agroecosystem services in Slovakia, with databases for the Slovak Republic.

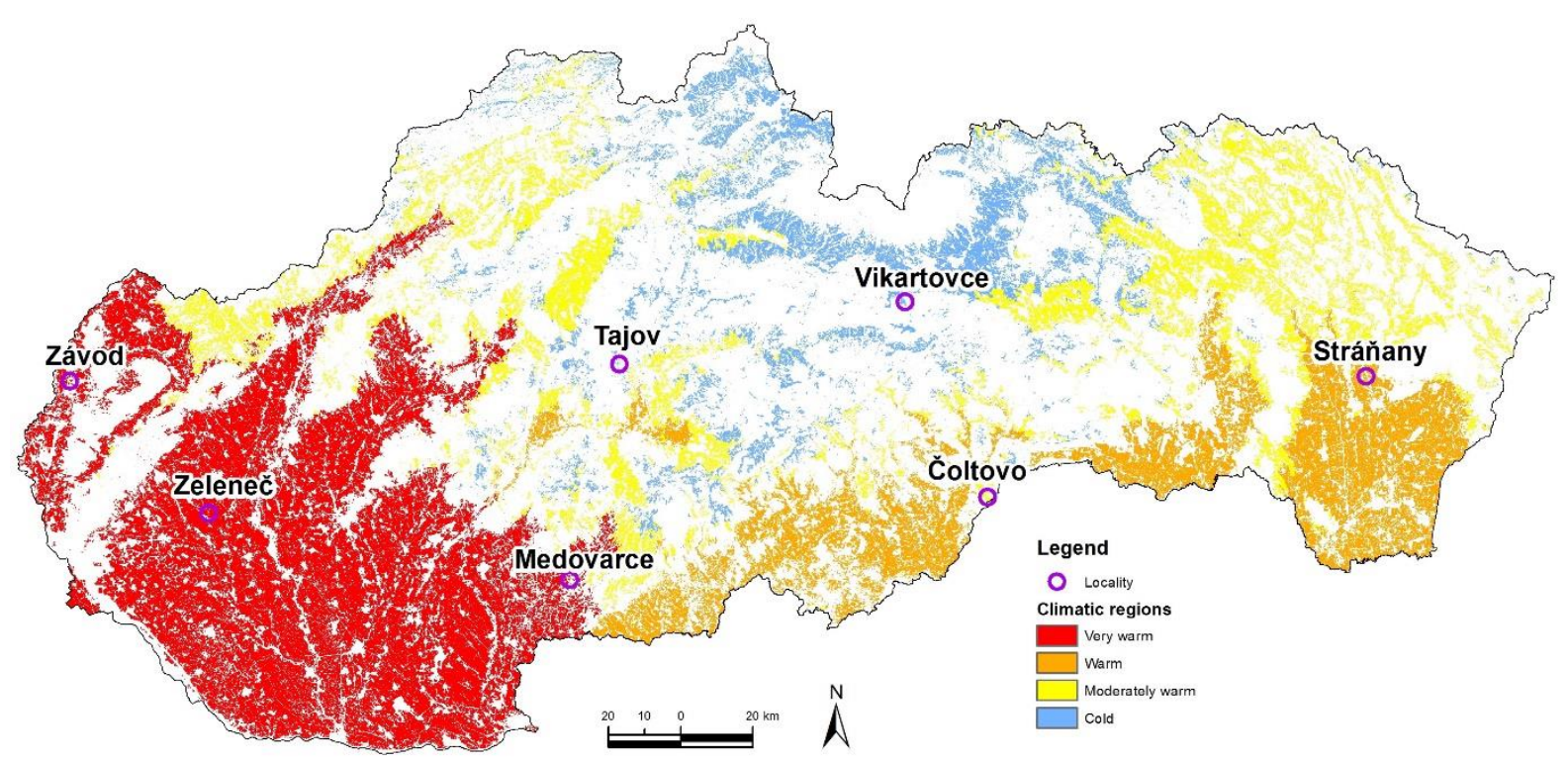

Fig 1. Study sites located in main climatic areas.

\subsection{Study area}

Slovakia is a land-locked country in Central Europe between latitudes $47^{\circ}$ and $49^{\circ} \mathrm{N}$ and longitudes $15^{\circ}$ and $21^{\circ} \mathrm{E}$. The official statement of the Ministry of Agriculture and Rural Development of Slovak Republic is that Slovakia is considered a rural country; the only exception is the Bratislava metropolitan region.

\subsection{Data sources}

Two main data sources were used for non-monetary valuation and mapping - primary (spatial information on the soil bodies - Digital Soil Map of Slovakia and Land Parcel Identification System LPIS) and secondary geo-referenced data (data of relevant soil properties the Geochemical Atlas of Soils of Slovakia and Soil Monitoring of Slovakia). Climatic regions were evaluated on the basis of the soil quality information system code (BPEJ), in 4 categories: very warm (BPEJ code 00, 01, 02), warm (BPEJ code 03, 04, 05), moderately war, (BPEJ code 06, 07, 08) and cold climatic region (BPEJ code 09, 10). We did not use the CLC database as the underlying layer. However, the LPIS data are compatible with the CLC data and therefore the results can also be used to assess the category of arable land and grassland in the CLC ecosystem database. 


\section{Results and discussion}

The analysis of the individual categories of services is most appropriate through a comparison of their potential to fulfill these services (Mahbubul et al., 2016). The categories of provisioning, cultural and regulating agroecosystem services potential at model locations are shown in Figures 2 and 3. Tajov and Vikartovce locations have a low provisioning service potential due to the cold climate, higher altitude (TA - $647 \mathrm{~m}$ a.s.I., VI - $945 \mathrm{~m}$ a.s.I.) as well as lower soil quality (higher skeleton content and lower humus quality). Čoltovo and Závod locations belong to the category with a medium potential of provisioning services. The category with a high potential of provisioning services is represented by arable land ecosystem in the locations of Medovarce and Stráňany. Location Zeleneč, Chernozem, with an optimal texture and a high content of high-quality humus, represents the category with a very high provisioning potential.
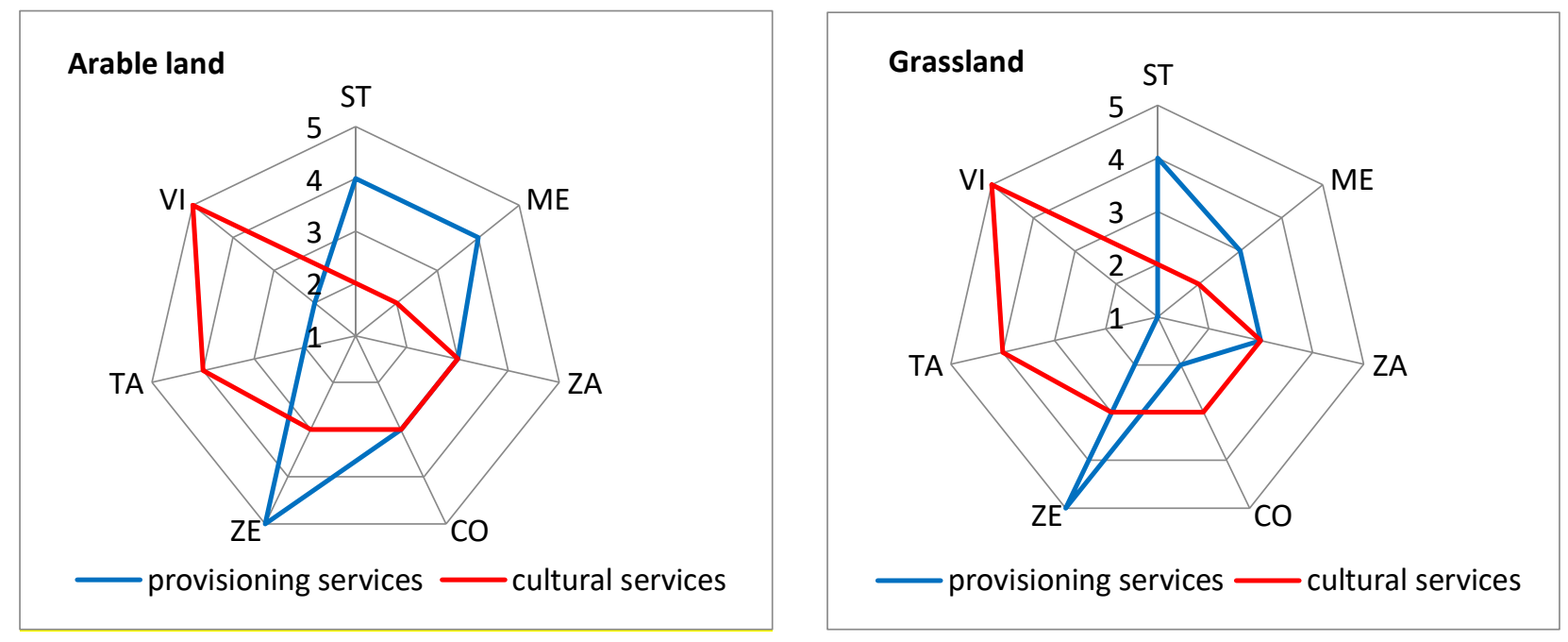

Fig 2. Potential categories of provisioning and cultural agro-ecosystem services at model sites (arable land and grassland). Localities: ST - Stráňany, ZE - Zeleneč, ZA - Závod (ZA), ME - Medovarce, CO - Čoltovo, TA Tajov, VI-Vikartovce. Categories of potential: 1 - very low, 2-low, 3- medium, 4- high, 5-very high
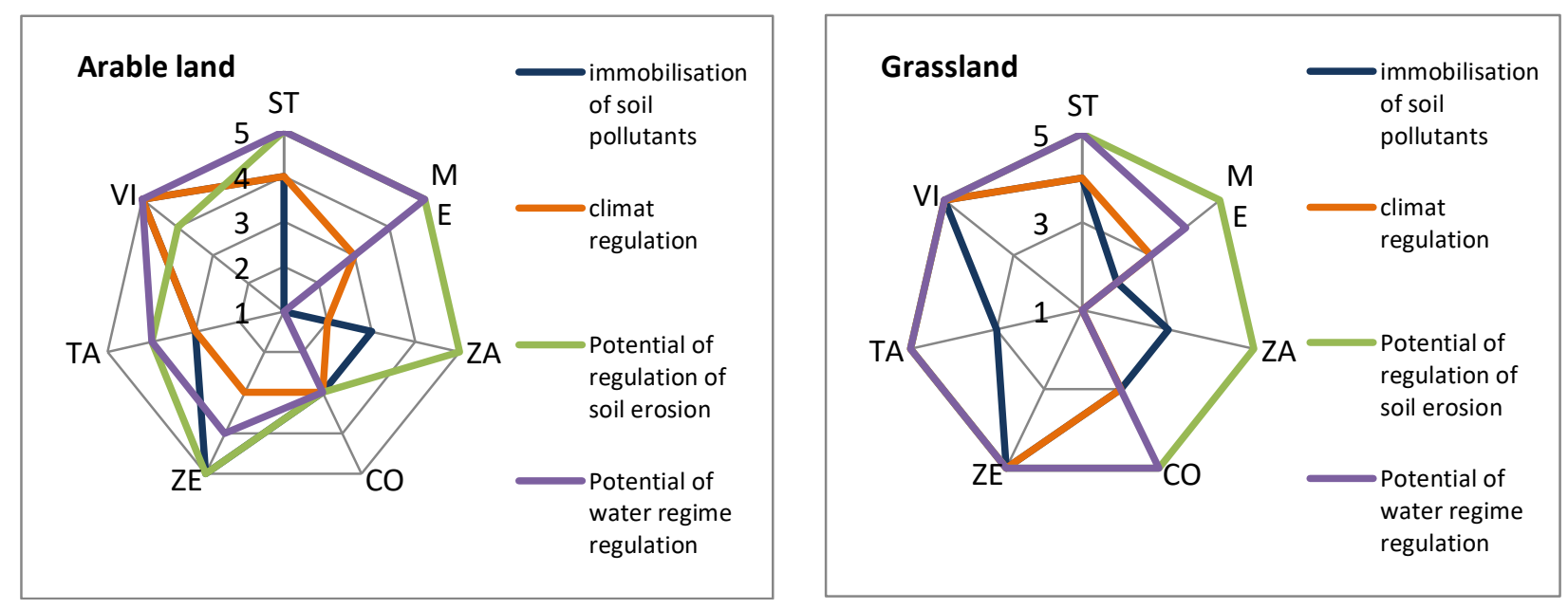

Fig 3. Categories of potential regulating agroecosystem services at model sites (arable land and grassland). Localities: ST - Stráňany, ZE - Zeleneč, ZA - Závod (ZA), ME - Medovarce, CO - Čoltovo, TA - Tajov, VIVikartovce. Categories of potential: 1 - very low, 2 - low, 3-medium, 4- high, 5-very high

Non-monetary assessment of agroecosystem services at model locations are illustrated in Figure 4 as a value of groups of agroecosystem services in non-monetary units. The agroecosystem services potential value of arable land and grassland sites located in different soil-ecological regions of Slovakia differ in all groups of services. The most significant differences are in provisioning and regulating services. At arable land, the non-monetary value 
of provisioning services is in contrast to the value of cultural services. Tajov and Vikartovce sites with a low value of production potential are better used for recreational purposes, which can help prevent degradation and loss of agricultural land. According to our results, the studied locations Stráňany, Medovarce and Zeleneč have higher values of provisioning services compared to the values of cultural services (outdoor recreation). Therefore, their provisioning services have first order priority with the exception of Medovarce location. This study site belongs to the polluted areas (by inorganic contamination) and therefore the soil is not able to fulfill its hygienic function. The site can be used for growing energy crops and it is more suitable as grassland or for production of energy crops. The comparison of the total value of agroecosystem services on locations with the same soil-ecological conditions but with different management (arable land vs. grassland) shows a higher value of agroecosystem services on arable land; only two locations (Zeleneč and Tajov) have a higher total value of grassland ecosystems and a higher value of regulating services (Figure 3 ). When assessing the agroecosystem in the context of CLC ecosystem categories, arable land has a higher capacity for the provision of production services and from a low to a very low potential in terms of the provision of regulating and cultural ecosystem services (Mederly et al., 2019).

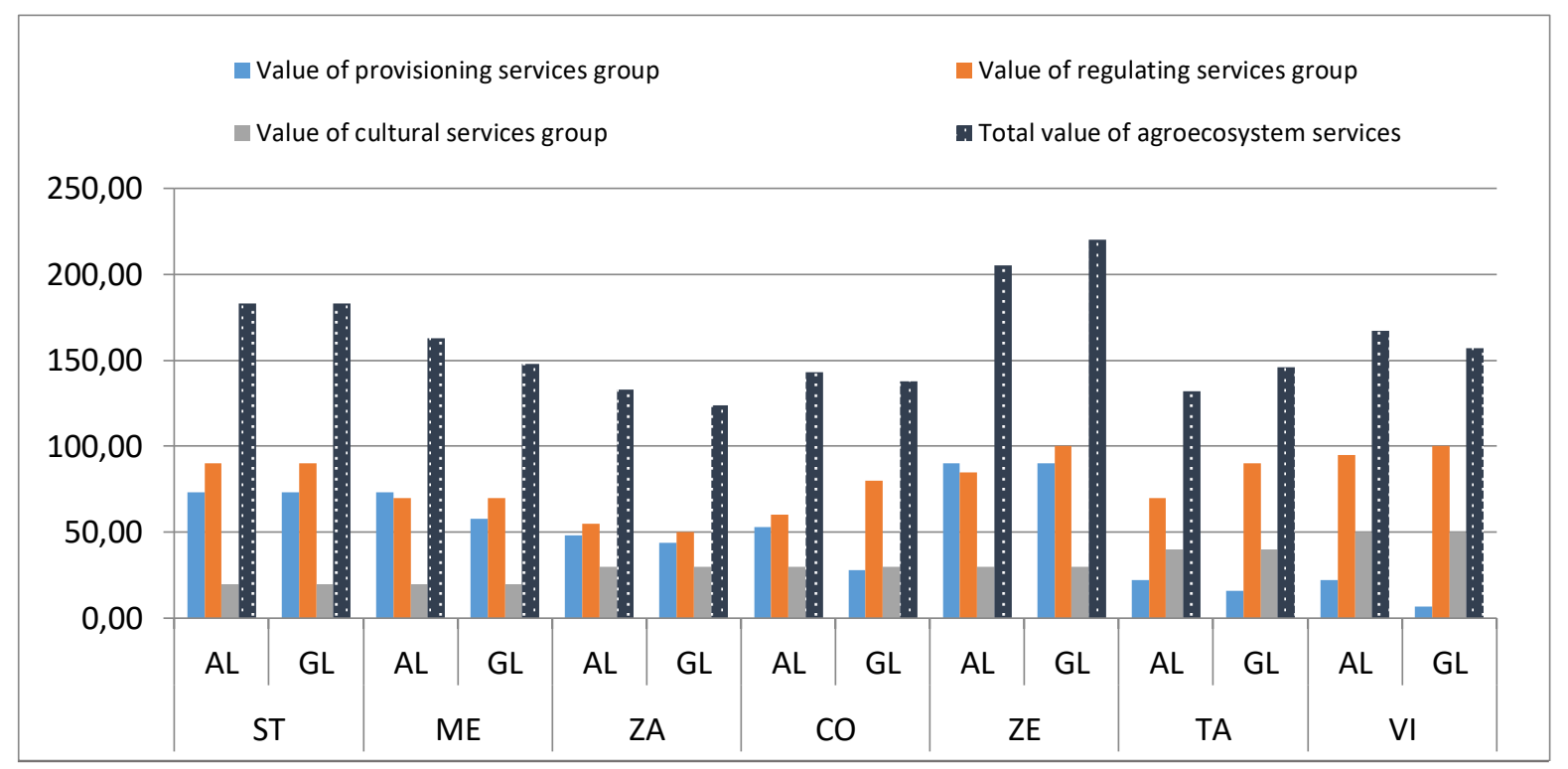

Fig 4. The value of groups of agroecosystem services at model locations in non-monetary units. Localities: ST Stráňany, ZE - Zeleneč , ZA - Závod (ZA), ME - Medovarce, CO - Čoltovo, TA - Tajov, VI -Vikartovce, AL arable land, $G L$ - grassland

The pilot non-monetary assessment of the country's capacity to provide agro-ecosystem services is shown in Figure 5. The average value of the sum of three groups of agroecosystem services (provisioning, regulating and cultural group) is 144.12 of non-monetary units in Slovakia (with a total area of 1,760,424 ha of arable land and 444,547 ha of grassland; with a minimum value of 80 and a maximum value of 194 units). The average value of provisioning agroecosystem services is 59.49 units. This value is higher for arable land (67.20 units) compared to grassland (36.68 units) and is determined by climatic conditions (temperature and precipitation), soil quality, morphological and socio-economic factors. The high values are obtained for ecosystems of arable land with high quality (mainly Chernozems) located in the Danube basin. Strongly skeletal soils of low quality located at higher altitudes in colder areas, mainly used as grassland, have low agroecosystem service values. Based on correlation analysis, the value of the provisioning service is significantly affected by climate, and slope (Table 1). Vilček (2014) reports high values of the ability of agricultural lands to perform environmental functions, which are the basis for fulfilling ecosystem services, on the Danubian lowland, and the lowest values in the Košice basin (another method of assessment of the territory of Slovakia has not been available yet). 


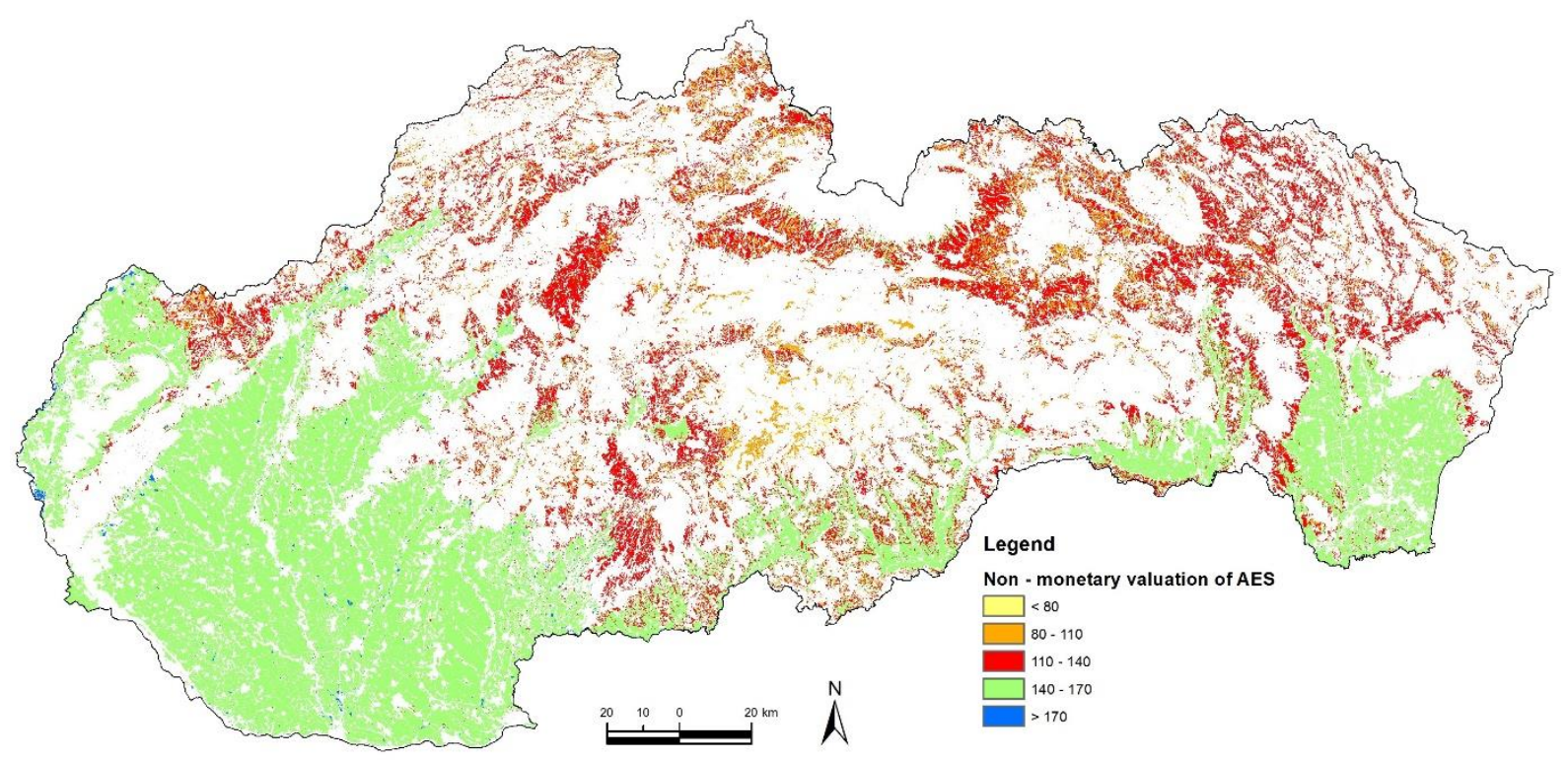

Fig 5. Non-monetary valuation of agroecosystem services (AES) in Slovakia.

The spatial mapping allows us to determine agroecosystem services values in relation to socioeconomic indicators, which are regions as territorial statistical units (NUTS 3). Figure 6 shows the average non-monetary values of agroecosystem services in all 8 NUTS 3 regions in Slovakia, where the highest average values belong to the provisioning services of the Nitra and Trnava NUTS regions.

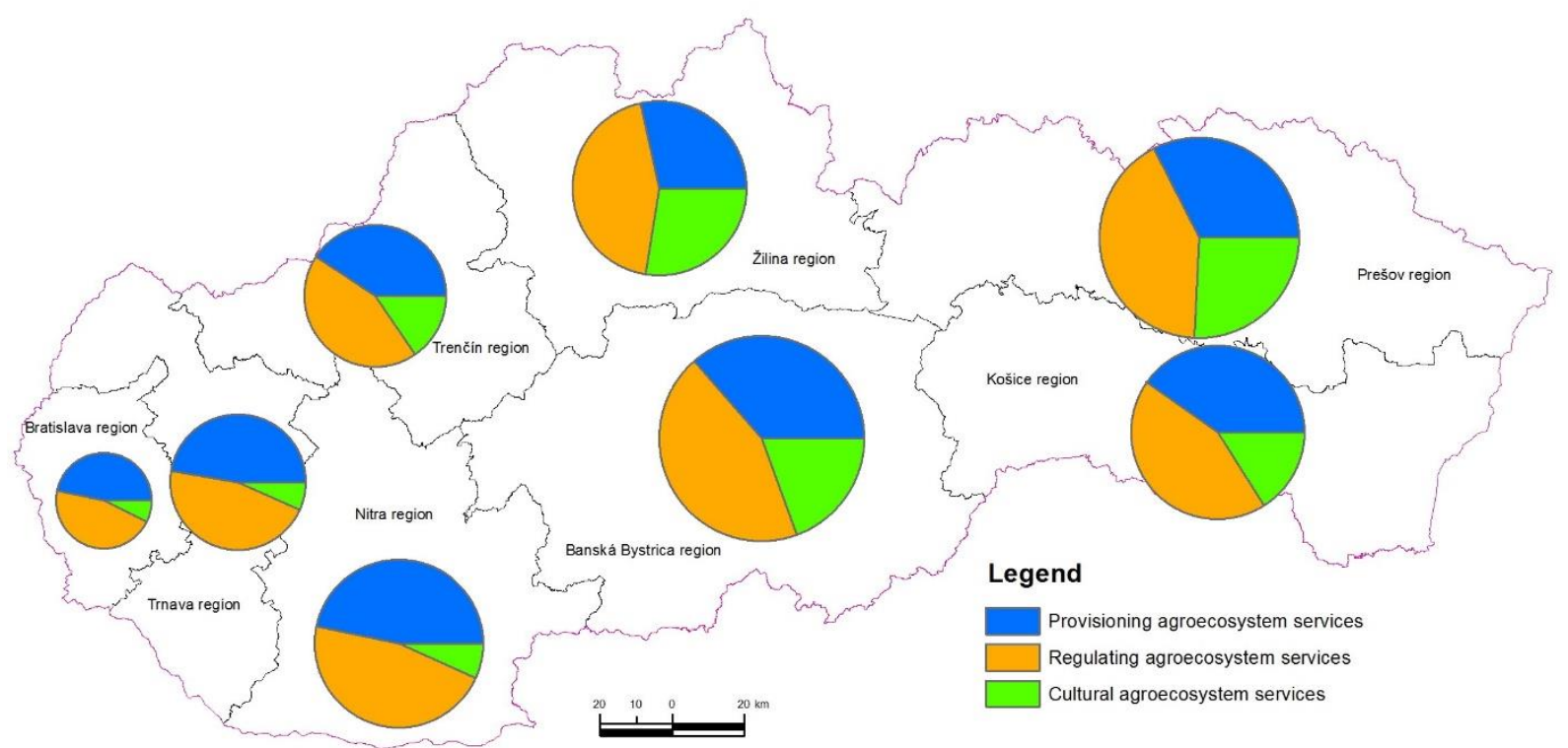

Fig 6. Non-monetary valuation of agroecosystem services in NUTS 3 regions of Slovakia (average value of AES).

The value of grassland ecosystem regulating services in Slovakia (62.74 units) is higher than that of arable land ecosystems (50.78 units). The total value of the four groups of regulating services of agroecosystems is 53.79 of non-monetary units. The value of the potential of regulating ecosystem services is characterized by natural capital stocks and flows of ecosystem services (Constanza, 2008). The overall value of the regulating services in Slovakia is significantly influenced by arable land ecosystems, which occupy a significantly larger area than grassland. Agroecosystems with a high value of water regulation potential are mainly on arable land (Chernozems, Fluvisols and Phaeozems on carbonateous fluvial sediments) located in the Danube lowland or in the Danube basin (Nitra region, Trnava region), or in the floodplains of middle and lower rivers. The main part of arable land is located on flatter lands where there is 
less risk of water erosion and soil drainage. In agroecosystems, vegetation is primarily responsible for regulating soil drainage. The main factors directly affecting erosion control are those that jeopardize the integrity of the vegetation cover.

High carbonate arable soil ecosystems developed on loess located on the Danube (Nitra region, Trnava region) and East Slovakian lowlands (Košice region) without anthropogenic and geochemical deposition also have a high value of soil purification potential (immobilization of inorganic pollutants) due to optimal soil (Makovníková, 2001; Donisa et al., 2003; Borůvka and Drábek, 2004; Makovníková et al., 2007; Makovníková and Barančíková, 2009). The areas with a low value of water regime regulation potential mainly consist of permanent grassland ecosystems developed on shallow and heavily skeletal soils of the most common types of Cambisols, Rendzic, Leptosols rendzina and Phaeozems on non-carbonaceous fluvial sediments. The main indicator of the potential climate control service is organic carbon content of the soil (Forouzangohar et al., 2014). Grassland agroecosystems have a higher ability to sequester organic carbon in soil than arable ecosystems (Barančíková et al., 2018), and thus their climate control value, which contributes to overall regulating services, is higher in comparison with arable land ecosystems.

The values of cultural agroecosystem services in Slovakia range from 10 to 50 units, with an average value for arable land of 33.15 non-monetary units (with a maximum value of 40), grassland 24 units (with a maximum value of 50 non-monetary units) and soils and grasslands 30.84 non-monetary units. The value of agroecosystems for the provision of recreational services depends on several factors. It is influenced by the uniqueness of the site, its accessibility as well as the surrounding infrastructure (Maes et al., 2012). Many farmers analyze the possibilities of using agricultural land not only for production but also for agro-tourism and ecotourism (Parente and Bovolenta, 2012), which may represent an additional source of income, especially for agroecosystems with a lower production service potential. According to several authors (Burkhard et al., 2009; Joyce and Sutton, 2009; Maes et al., 2011), within the overall assessment of ecosystems (forest, aquatic ecosystem etc.), agroecosystems values range predominantly from very low to low potential for natural recreation. In the case of arable land ecosystem, the value of the potential for natural recreation in the assessment of a particular region may be lower compared to the value of the grassland potential (Makovníková et al., 2016). Grassland agroecosystems in Slovakia are located closer to NATURA 2000 protected areas, in areas with a higher slope and a higher altitude than arable land ecosystems. The value of the potential for recreation is increasing in areas with cooler climates, which has increased the value of this group of arable land services due to their higher area coverage even in colder areas compared to grassland. These results are consistent with the status of soil, its properties, processes and functions in the concept of agroecosystem services (Burkhard et al., 2009; Bujnovský et al., 2011; Makovníková et al., 2017).

As shown in Figure 5, the distribution of the value of agroecosystem services is geographically different. The climatic conditions, slope or soil texture and land use affected either positively or negatively the value of non-monetary ecosystem services (Table 1). According to Burkhard et al. (2014) and Frélichová and Fanta (2015), the climate has an important impact on the distribution of the agroecosystem services potential, thus on the distribution of the nonmonetary values of agroecosystem services, as well.

According to Yang et al. (2019), all the provisioning and regulating services were determined by common geographic conditions, climate and human activities. Our results also show that the major factor influencing the distribution of non-monetary values of agroecosystem services is climate (Table 1). Climate also affects the management possibilities and land use. 
Tab 1. Spearman correlations coefficients.

\begin{tabular}{|c|c|c|c|c|}
\hline \multirow[t]{2}{*}{ Agricultural land } & \multicolumn{4}{|c|}{ Non-monetary value } \\
\hline & $\begin{array}{l}\text { Provisioning } \\
\text { services }\end{array}$ & $\begin{array}{l}\text { Regulating } \\
\text { services }\end{array}$ & $\begin{array}{l}\text { Cultural } \\
\text { services }\end{array}$ & $\begin{array}{l}\text { Agroecosystem } \\
\text { services }\end{array}$ \\
\hline Climatic region & $-0.76^{\star \star \star}$ & $0.53^{\star \star \star}$ & $0.39^{*}$ & $-0.33^{*}$ \\
\hline Soil texture & $0.22 \mathrm{~ns}$ & $-0.10 n s$ & $0.35^{\star}$ & $0.27 n s$ \\
\hline Slope & $-0.49^{\star \star}$ & $-0.10 \mathrm{~ns}$ & $-0.10 \mathrm{~ns}$ & $-0.40^{\star *}$ \\
\hline \multirow[t]{2}{*}{ Arable land } & \multicolumn{4}{|c|}{ Non-monetary value } \\
\hline & $\begin{array}{l}\text { Provisioning } \\
\text { services }\end{array}$ & $\begin{array}{l}\text { Regulating } \\
\text { services }\end{array}$ & $\begin{array}{l}\text { Cultural } \\
\text { services }\end{array}$ & $\begin{array}{l}\text { Agroecosystem } \\
\text { services }\end{array}$ \\
\hline Climatic region & $-0.82^{\star \star \star}$ & $0.40^{\star \star}$ & $-0.56^{\star \star \star}$ & $-0.55^{\star \star \star}$ \\
\hline Soil texture & $-0.25 n s$ & $-0.15 n s$ & $0.27 n s$ & $0.19 \mathrm{~ns}$ \\
\hline Slope & $-0.47^{\star *}$ & $-0.10 \mathrm{~ns}$ & $-0.16 n s$ & $-0.41^{\star \star}$ \\
\hline \multirow[t]{2}{*}{ Permanent grassland } & \multicolumn{4}{|c|}{ Non-monetary value } \\
\hline & $\begin{array}{l}\text { Provisioning } \\
\text { services }\end{array}$ & $\begin{array}{l}\text { Regulating } \\
\text { services }\end{array}$ & $\begin{array}{l}\text { Cultural } \\
\text { services }\end{array}$ & $\begin{array}{l}\text { Agroecosystem } \\
\text { services }\end{array}$ \\
\hline Climatic region & $-0.75^{\star \star \star}$ & $0.64^{\star \star \star}$ & $-0.19 n s$ & $-0.10 n s$ \\
\hline Soil texture & $0.10 \mathrm{~ns}$ & $0.10 \mathrm{~ns}$ & $0.45^{\star \star}$ & $0.34^{*}$ \\
\hline Slope & $-0.55^{\star \star \star}$ & $-0.05 n s$ & $0.15 \mathrm{~ns}$ & $-0.41^{\star \star}$ \\
\hline
\end{tabular}

Significance labels: ${ }^{* *} p<0.001,{ }^{* *} p<0.01,{ }^{*} p<0.05$, ns- non significant

Identifying the areas with a low and high value of ecosystem services is crucial for land use management (Hamann et al., 2015, Pandeya et al., 2016). In Slovakia, there are low nonmonetary values of provisioning services mainly in the Žilina and Prešov regions (areas with a cold to moderately warm climate, higher slopes and a higher percentage of clay particles in soil texture) (Table 1, Figure 5, 6). A warm, dry lowland region has a higher value of provisioning services (Nitra, Bratislava and Trnava region) as well as cultural services than moderately warm and cold regions. Moderately warm and cold climatic regions have high shares of high value of regulating services. Synergies within regulating services and trade-offs between service provision and regulation are cited by several authors (Wang et al., 2015; Makovníková et al., 2018; Yang et al., 2019).

In Slovakia, regulating services values were higher in moderately warm and cold climatic regions. These findings are consistent with Bommarco et al. (2013) and Barančíková et al. (2018), where regulating service values were also higher in colder climatic areas due to ecosystems of grassland with a high carbon content and thus a high value of climate regulation (Yang et al., 2019). Grassland agroecosystems also have a high value of soil erosion control caused by water erosion. Soil biomass is involved in the control of soil removal, which reduces the kinetic energy of the incident raindrops, thereby reducing their effect on soil particles on the surface and preventing the formation of a poorly permeable soil layer. Above-ground biomass captures large amounts of water on its surface, reducing the rate of surface runoff and contributing to its reduction. Agroecosystems perform climate regulation ecosystem service only in case they increase the amount of captured carbon in organic matter from year to year. 


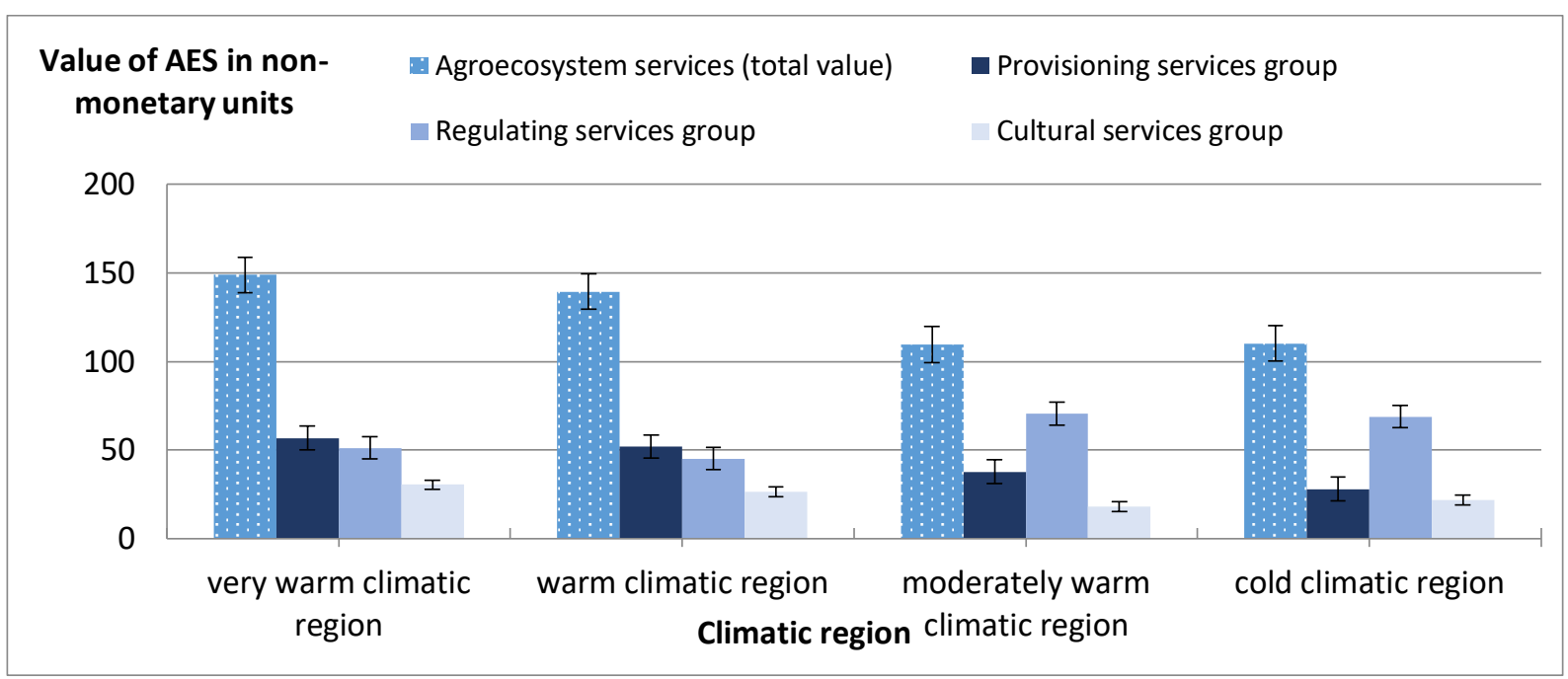

Fig 7. The value of agroecosystem services in non-monetary units in different climate regions of Slovakia.

\section{Conclusion}

We have focused on assessment and mapping of the value of different agroecosystem services as one of the most important objectives of the updated National Biodiversity Strategy to 2020, which is a key document in the field of biodiversity protection in the Slovak Republic. Nonmonetary assessment and mapping of agroecosystem services in the Slovak Republic allows us to combine the analysis of land use and the differences in the values of a particular group of agroecosystem services in different areas of Slovakia. The total value of ecosystem services of agricultural land in Slovakia is $309910^{*} 10^{7}$ non-monetary units (the value of ecosystem services of arable land is $235394^{*} 10^{7}$ and the value of grassland is $74516^{*} 10^{7}$ ). The highest average value of agroecosystem services is in the Trnava region and the lowest in the Zilina region. This study suggests that the distribution of the value of agroecosystem services is geographically different probably due to climatic conditions, slope and soil texture. Provisioning services as well as cultural services have higher values in the warm, dry lowland regions than in moderately warm and cold regions. These findings could be used in sustainable agriculture land use management of rural areas in Slovakia. The methodology used can be tested and developed also in other geographical areas as a non-monetary assessment tool within agroecosystem services to provide policy-makers with relevant supporting information about overall progress towards the targets defined for international, national and regional sustainable/biodiversity strategies.

Our non-monetary valuation of agroecosystem services is based on a spatial grid scheme which is replicable and could be applied by stakeholders and citizens with proficient skills in geographical information systems. The designed mapping system can be linked to socioeconomic indicators at district level. For the pilot valuation of agroecosystem services in Slovakia, we have chosen non-monetary units that represent "relational values of nature" (Stálhammar, 2019). These values can be replaced by specific biophysical units or monetary values based on specialized research or the value (benefit) transfer method from known valuation studies of ecosystem services (Frélichová et al., 2014; Menderly et al., 2019). All indicators of our valuation have been aggregated into a $100 \mathrm{~m} \times 100 \mathrm{~m}$ grid for consistency, which enables to compile agroecosystem values at local, regional and national level. This detailed view also provides information about the potential of agroecosystem services in a particular territory, which can be of benefit for different stakeholders and offer an alternative perspective of managing the country more sustainably. The obtained values represent the most suitable indicator characteristics derived from the data used. One of the benefits of this approach is also the possibility to monitor the dynamics of the value of natural capital and thereby manage its optimal use, and to deal with trade-offs and synergy effects in the benefit of sustainable development. Implementing the value of ecosystem services of natural capital into public decision-making will allow effective assessment, monitoring and 
utilization of this natural source in the context of economic, human and cultural capital of individual regions.

Our assessment combines several dimensions (ecological, economic, and cultural) and can help to use the natural capital of the region in spatial planning more efficiently, and integrate the perception of stakeholders in decision-making processes and thereby contribute to optimizing sustainable land use management. For example, on highly fertile soils, no industrial or other construction should be planned. The production of agricultural crops should respect more the potential of agroecosystem services in a given area rather than the subsidy schemes. Our results of mapping the agroecosystem services can also be of use for the Ministry of Agriculture and Rural Development of the Slovak Republic, as one of its priorities is to grow agricultural crops on a smaller scale and in a more diverse structure than at present. This should be investigated more in-depth in the future. For the future, this study also suggests that a combination of monetary and non-monetary assessment methods is needed to provide a comprehensive picture of the value and sustainable outcomes of agroecosystem services (Kenter, 2016). In Slovakia, further research in agroecosystem services will require regular collection and availability of data.

\section{Acknowledgement}

The authors acknowledge the Slovak Research and Development Agency for the financial support via contract No. APVV-0098-12 and APVV- 18-0035 "Valuing ecosystem services of natural capital as a tool for assessing the socio-economic potential of the area". We would also like to thank the anonymous reviewers for helpful comments.

Academic references

[1] Alam, M., Dupra J. \& Messier, Ch. (2016). A framework towards a composite indicator for urban ecosystem services. Ecological indicators 60, 38-44. DOI: 10.1016/j.ecolind.2015.05.035.

[2] Barančíková, G., Jerzykiewicz, M., Gömöryová, E., Tobiášová, E. \& Litavec, T. (2018). Correction to: Changes in forest soil organic matter quality affected by windstorm and wildfire. Journal of Soils and Sediments 18 (8), 2738-2747. DOI: 10.1007/s11368-0181979-2.

[3] Birkhofer, K., Diehl, E., Andersson, J., Ekroos, J., Früh-Müller, A., Machnikowski, F., Mader, V. L., Nilsson, L., Sasaki, K., Rundlöf, M., Wolters, V. \& Smith, H. G. (2015). Ecosystem services-current challenges and opportunities for ecological research. Frontiers in Ecology and Evolution 2. DOI: 10.3389/fevo.2014.00087.

[4] Bommarco, R., Kleijn, D. \& Potts, S. G. (2013). Ecological intensification: harnessing ecosystem services for food security. Trends in Ecology \& Evolution 28(4), 230-238. DOI: 10.1016/j.tree.2012.10.012.

[5] Borůvka, L. \& Drábek, O. (2004). Heavy metal distribution between fractions of humic substances in heavily polluted soils. Plant, Soil and Environment 50, 339-345. DOI: 10.17221/4041-pse.

[6] Bujnovský, R., Vilček, J., Blaas, G., Skalský, R., Barančíková, G., Makovníková, J., Balkovič, J. \& Pálka, B. (2011). Hodnotenie kapacít pôdy a efektov z jej využívania. Bratislava: Soil Science and Conservation Research Institute.

[7] Bullock, J. M., Pywell, R. F. \& Walker, K. J. (2006). Long-term enhancement of agricultural production by restoration of biodiversity. Journal of Applied Ecology 44(1), 6-12. DOI: 10.1111/j.1365-2664.2006.01252.x.

[8] Bürgi, M., Silbernagel, J., Wu, J. \& Kienast, F. (2014). Linking ecosystem services with landscape history. Landscape Ecology 30(1), 11-20. DOI: 10.1007/s10980-014-0102-3. 
[9] Burkhard, B., Crossman, N., Nedkov, S., Petz, K. \& R. Alkemade (2013). Mapping and modelling ecosystem services for science, policy and practice. Ecosystem Services 4, 1-3. DOI: 10.1016/j.ecoser.2013.04.005.

[10] Burkhard, B., Kandziorai, M. S. \& Müller, F. (2014). Ecosystem service potentials, flows and demands - Concepts for spatial localisation, indication and quantification. (IALE-D). Landscape Online 34, 1-32. DOI: 10.3097/LO.201434.

[11] Burkhard, B., Kroll, F., Müller, F. \& Windhorst, W. (2009). Landscapes capacities to provide ecosystem services - A concept for land-cover based assessments. Landscape Online 15, 1-22. DOI: 10.3097/LO.200915.

[12] Burkhard, B., Kroll, F., Nedkov, S. \& Müller, F. (2012). Mapping ecosystem service supply, demand and budgets. Ecological Indicators 21, 17-29. DOI: 10.1016/j.ecolind.2011.06.019.

[13] Costanza, R. (2008). Ecosystem services: multiple classification systems are needed. Biological Conservation 141(2), 350-352. DOI: 10.1016/j.biocon.2007.12.020.

[14] Costanza, R. \& Daly, H. E. (1992). Natural capital and sustainable development. Conservation Biology 6 (1), 37-46. DOI: 10.1046/j.1523-1739.1992.610037.x.

[15] Costanza, R., De Groot, R., Braat, L., Kubiszewski, I., Fioramonti, L., Sutton, P., Farber, S. \& Grasso, M. (2017). Twenty years of ecosystem services: How far have we come and how far do we still need to go? Ecosystem Services, 28, 1-16. DOI: 10.1016/j.ecoser.2017.09.008.

[16] Costanza, R., de Groot, R., Sutton, P., van der Ploeg, S., Anderson, S. J. \& Kubiszewski, I. (2014). Changes in the global value of ecosystem services. Global Environmental Change 26(1), 152-158, DOI: 10.1016/j.gloenvcha.2014.04.002.

[17] Crouzat, E., Mouchet, M., Turkelboom, F., Byczek, C., Meersmans, J., Berger, F., Verkerk, P. J. \& Lavorel, S. (2015). Assessing bundles of ecosystem services from regional to landscape scale: insights from the French Alps. Journal of Applied Ecology 52(5), 11451155. DOI: $10.1111 / 1365-2664.12502$.

[18] De Groot, R., Fisher, B., Christie, M., Aronson, J., Braat, L., Haines-Young, R., Gowdy, J., Maltby, E., Neuville, A., Polasky, S., Portela, R. \& Ring, I. (2010). Integrating the ecological and economic dimensions in biodiversity and ecosystem service valuation. In Kumar, P., ed., TEEB Foundations, The Economics of Ecosystems and Biodiversity: Ecological and Economic Foundations (pp. 9-40). London: Earthscan. DOI: 10.4324/9781849775489.

[19] Donisa, C., Mocanu, R. \& Steinnes, E. (2003). Distribution of some major and minor elements between fulvic and humic acid fractions in natural soils. Geoderma 111, 75-84. DOI: 10.1016/S0016-7061(02)00254-9.

[20] Džatko, M. (2002). Hodnotenie produkčného potenciálu pol'nohospodárskych pôd a pôdnoekologických regiónov Slovenska. Bratislava: Soil Science and Conservation Research Institute.

[21] Faccioni, G., Sturaro, E., Ramanzin, M. \& Bernués, A. (2019). Socio-economic valuation of abandonment and intensification of Alpine agroecosystems and associated ecosystem services. Land Use Policy 81, 453-462. DOI: 10.1016/j.landusepol.2018.10.044.

[22] Forouzangohar, M., Crossman, N. D., MacEwan, R. J., Wallace, D. D. \& Bennett, L. T. (2014). Ecosystem Services in Agricultural Landscapes: A Spatially Explicit Approach to Support Sustainable Soil Management. The Scientific World Journal article ID 483298. DOI: $10.1155 / 2014 / 483298$.

[23] Frélichová, J. \& Fanta, J. (2015). Ecosystem service availability in view of long -term landuse changes: a regional case study in the Czech Republic. Ecosystem Health and Sustainability 1, 1-15. DOI: 10.1890/EHS15-0024.1. 
[24] Frélichová, J., Vačkář, D., Pártl, A., Loučková, B., Harmáčková, Z. V. \& Lorencová, E. (2014). Integrated Assessment of Ecosystem Services in the Czech Republic. Ecosystem Services 8, 110-117. DOI: 10.1016/j.ecoser.2014.03.001.

[25] Füzyová, L'., Lániková, D. \& Novorolský, M. (2009). Economic valuation of Tatras national park and regional environmental policy. Polish Journal of environmental studies 18 (5), 811-818.

[26] Garbach, K., Milder, J. C., Montenegro, M., Karp, D. S. \& DeClerck, F. A. J. (2014). Biodiversity and Ecosystem Services in Agroecosystems. In van Alfen, N., ed., Encyclopedia of Agriculture and Food Systems $2^{\text {nd }}$ ed. Cambridge, MA: Academic Press. (pp. 21-40). DOI: 10.1016/b978-0-444-52512-3.00013-9.

[27] Getzner, M. (2010). Economic and cultural values related to Protected Areas. Der Öffentliche Sektor 36(1-2), 44-64.

[28] Girardin, P., Bockstaller, C. \& van der Werf, H. M. (1999). Indicators: Tools to evaluate the environmental impacts of farming systems. Journal of Sustainable Agriculture 13(4), 521. DOI: 10.1300/J064v13n04_03.

[29] Gomez-Sal, A., Belmontes, J. A. \& Nicolau, J. M. (2003). Assessing landscape values: a proposal for a multi-dimensional conceptual model. Ecological Modelling 168 (3), 319341. DOI: 10.1016/S0304-3800(03)00144-3.

[30] Grêt-Regamey, A., Weibel, B., Bagstad, K. J., Ferrari, M., Geneletti, D., Klug, H., Schirpke, U. \& Tappeiner, U. (2014). On the Effects of Scale for Ecosystem Services Mapping. PLoS ONE 9(12), e112601. DOI: 10.1371/journal.pone.0112601.

[31] Hamann, M., Biggs, R. \& Reyers, B. (2015). Mapping social-ecological systems: Identifying 'green-loop' and 'red-loop' dynamics based on characteristic bundles of ecosystem service use. Global Environmental Change 34, 218-226. DOI: 10.1016/j.gloenvcha.2015.07.008.

[32] Hein, L., van Koppen, K., de Groot, R. S. \& van lerland, E. C. (2006). Spatial scales, stakeholders and the valuation of ecosystem services. Ecological Economics 57(2), 209228. DOI: 10.1016/j.ecolecon.2005.04.005.

[33] Chan, K. M. A., Guerry, A. D., Balvanera, P., Klain, S., Satterfield, T., Basurto, X., Bostrom, A. \& Chuenpagdee, R. (2012). Where are cultural and social in ecosystem services? A framework for constructive engagement. BioScience 62, 744-756. DOI: 10.1525/bio.2012.62.8.7.

[34] Joyce, K. \& Sutton, S. (2009). A method for automatic generation of the recreation opportunity spectrum in New Zealand. Applied Geography 29 (3), 409-418. DOI: 10.1016/j.apgeog.2008.11.006.

[35] Kenter, J. O. (2016). Editorial: Shared, plural and cultural values. Ecosystem Services 21, 175-183. DOI: 10.1016/j.ecoser.2016.10.010.

[36] Kizeková, M., Hopkins, A., Kanianska, R., Makovníková, J., Pollák, Š. \& Pálka, B. (2018). Changes in the area of permanent grasslands and its implications for the provision of bioenergy: Slovakia as a case study. Grass and Forage Science 73(1), 218-232. DOI: $10.1111 / \mathrm{gfs} .12333$.

[37] Krammer, J. \& Rohrmoser, F. (2012). Im Kampf um ihre Rechte. Geschichte der Bauern und Bäuerinnen in Österreich. Wien: ProMedia.

[38] Kurz, P. (2018). Between Smallholder Traditions and "Ecological Modernisation" Agricultural Transformation, Landscape Change and the Cap in Austria 1995-2015. European Countryside 10(1), 158-179. DOI: 10.2478/euco-2018-0010.

[39] Kušar, S. (2019). Green Infrastructure as a Facilitator of Sustainable Spatial Development in Rural Areas: Experiences from The Vipava Valley (Slovenia). European Countryside 11(1), 17-28. DOI: 10.2478/euco-2019-0002. 
[40] Lamarque, P., Tappeiner, U., Turner, C., Steinbacher, M., Bardgett, R. D., Szukics, U., Schermer, M. \& Lavorel, S. (2011). Stakeholder perceptions of grassland ecosystem services in relation to knowledge on soil fertility and biodiversity. Regional Environmental Change 11(4), 791-804. DOI: 10.1007/s10113-011-0214-0.

[41] Lorencová, E., Frélichová, J., Nelcon, E. \& Vačkář, D. (2013). Past and future impacts of land use and climate change on agricultural ecosystem services in the Czech Republic. Land Use Policy 33, 183-194. DOI: 10.1016/j.landusepol.2012.12.012.

[42] Lovell, S. T., DeSantis, S., Nathan, C. A., Olson, M. B., Méndez, V. E., Kominami, H. C., Erickson, D. L., Morris, K. S. \& Morris, W. B. (2010). Integrating agroecology and landscape multifunctionality in Vermont: an evolving framework to evaluate the design of agroecosystems. Agricultural Systems 103(5), 327-341. DOI: 10.1016/j.agsy.2010.03.003.

[43] Maes, J., Hauck, J., Paracchini, M. L., Ratamäki, O., Termansen, M., Perez-Soba, M., Kopperoinen, L., Rankinen, K., Schägner, J. P., Henrys, P., Cisowska, I., Zandersen, M., Jax, K., La Notte, A., Leikola, N., Pouta, E., Smart, S., Hasler, B., Lankia, T., Andersen, HE., Lavalle, C., Vermaas, T., Hussen Alemu, M., Scholefield, P., Batista, F., Pywell, R., Hutchins, M., Blemmer, M., Fonnesbech-Wulff, A., Vanbergen, A. J., Münier, B., Baranzelli, C., Roy, D., Thieu, V., Zulian, G., Kuussaari, M., Thodsen, H., Alanen, E. L., Egoh, B., Borgen Sørensen, P., Braat, L. \& Bidoglio, G. (2011). A spatial assessment of ecosystem services in Europe: methods, case studies and policy analysis-phase 1. [research report]. ISPRA (Partnership for European Environmental Research).

[44] Maes, J., Burkhard, B. \& Geneletti, D. (2018). Ecosystem services are inclusive and deliver multiple values. A comment on the concept of nature's contributions to people. One Ecosystem 3, e24720. DOI: 10.3897/oneeco.3.e24720.

[45] Maes, J., Egoh, B., Willemen, L., Liquete, C., Vihervaara, P., Schägner, J. P., Grizzetti, B., Drakou, E. G., La Notte, A., Zulian, G., Bouraoui, F., Paracchini, M. L., Braat, L. \& Bidoglio, G. (2012). Mapping ecosystem services for policy support and decision making in the European Union. Ecosystem Services 1(1), 31-39. DOI: 10.1016/j.ecoser.2012.06.004.

[46] Mahbubul, A., Dupras, J. \& Messier, CH. (2016). A framework towards a composite indicator for urban ecosystem services. Ecological indicators 60, 38-44. DOI: 10.1016/j.ecolind.2015.05.035.

[47] Makovníková, J., Pálka, B., Širáň, M., Kanianska, R., Kizeková, M. \& Jad'ud’ová, J. (2017). Modelovanie a hodnotenie agroekosystémových služieb. Banská Bystrica: Belianum.

[48] Makovníková, J. (2001). Distribution of $\mathrm{Cd}$ and $\mathrm{Pb}$ in main soil types of Slovakia. Agriculture 47, 903-912.

[49] Makovníková, J. \& Barancíková, G. (2009). Assessment of Transport Risk of Cadmium and Lead on the Basis of Immobilisation Capability of Soil. Soil and Water Research 4(1), 10 16. DOI: 10.17221/31/2008-SWR.

[50] Makovníková, J., Barančíková, G. \& Pálka, B. (2007). Approach to the assessment of transport risk of inorganic pollutants based on the immobilisation capability of soil. Plant, Soil and Environment 53, 365-373. DOI: 10.17221/2215-PSE.

[51] Makovníková, J., Kobza, J., Pálka, B., Mališ, J., Kanianska, R. \& Kizeková, M. (2016). An approach to mapping the potential of cultural agroecosystem services, Soil and Water Research 11, 44-52. DOI: 10.17221/109/2015-SWR.

[52] Makovníková, J., Pálka, B., Širáň, M., (...), Kanianska, R. \& Kizeková, M. (2019). An approach to the assessment of regulating agroecosystem services. Polish Journal of Soil Sciences 52(1), 95-112 DOI: 10.17951/pjss/2019.52.1.95.

[53] Makovníková, J., Pálka, B., Širáň, M., Houšková, B., Kanianska, R. \& Kizeková, M. (2018). Ecosystem services in differently used agroecosystems along an climatic gradient in Slovakia. Open Journal of Ecology 8(12), 623-645. DOI: 10.4236/oje.2018.812037. 
[54] Mederly, P. \& Černecký, J. et al. (2019). Katalóg ekosystémových služieb Slovenska. Banská Bystrica/Nitra: Štátna ochrana prírody SR, Institute of Landscape Ecology Slovak Academy of Sciences, Konstantin the Philosper University.

[55] Olander, L. P., Johnston, R. J., Tallis, H., Kagan, J., Maguire, L. A., Polasky, S., Urban, D., Boyd, J., Wainger, L. \& Palmer, M. (2018). Benefit relevant indicators: Ecosystem services measures that link ecological and social outcomes. Ecological Indicators 85, 1262-1272. DOI: 10.1016/j.ecolind.2017.12.001.

[56] Pandeya, B., Buytaert, W., Zulkafli, Z., Karpouzoglou, T. F., Mao, F. \& Hannah, D. M. (2016). A comparative analysis of ecosystem services valuation approaches for application at the local scale and in data scarce regions. Ecosystem Services 22, 250-259. DOI: 10.1016/j.ecoser.2016.10.015.

[57] Parente, G. \& Bovolenta, S. (2012). The role of grassland in rural tourism and recreation in Europe, In Grassland - a European Resource? Grassland Science in Europe 17,733-743.

[58] Plieninger, T., Schleyer, C., Schaich, H., Ohnesorge, B., Gerdes, H., Hernández-Morcillo, M. \& Bieling, C. (2012). Mainstreaming ecosystem services through reformed European agricultural policies. Conservation Letters 5(4), 281-288. DOI: 10.1111/j.1755263x.2012.00240.x.

[59] Považan, R. (2011). Economic and Cultural Values Related to the Velká Fatra National Park (Slovakia) [Master thesis]. Klagenfurt: Alpen-Adria-University.

[60] Považan, R. (2013). Rekreačné hodnoty NP Vel'ká Fatra. Acta Universitatis Matthiae Belii Environmental management Series 15 (1), 82-94.

[61] Power, A. G. (2010). Ecosystem services and agriculture: tradeoffs and synergies. Philosophical Transactions of the Royal Society B 365, 2959-2971. DOI: $10.1098 /$ rstb.2010.0143.

[62] Randall, A. (2007). A consistent valuation and pricing framework for non-commodity outputs: progress and prospects. Agriculture, Ecosystems and Environment 120 (1), 2130. DOI: 10.1016/j.agee.2006.03.036.

[63] Seják, J., Cudlín, P., Pokorný, J., Zapletal, M., Petříček, V., Guth, J., Chuman, T., Romportl, D., Skořepová, I., Vacek, V., Vyskot, I., Černý, K., Hesslerová, P., Burešová, R., Prokopová, M., Plch, R., Engstová, B. \& Stará, L. (2010). Hodnocení funkcí a služeb ekosystémů České republiky. Ústí nad Labem: Jan Evangelista Purkyně University.

[64] Seják, J., Dejmal, I., Petř́ček, V., Cudlín, P., Míchal, I., Černý, K., Kučera, T., ..., Zapletal, J. (2003). Hodnocení a oceňovaní biotopù České republiky. Praha: Český ekologický ústav.

[65] Schirpke, U., Leitinger, G., Tasser, E., Schermer, M., Steinbacher, M. \& Tappeiner, U. (2012). Multiple ecosystem services of a changing Alpine landscape: past, present and future. International Journal of Biodiversity Science, Ecosystem Services \& Management 9(2), 123-135. DOI: 10.1080/21513732.2012.751936.

[66] Stálhammar, S. \& Thorén, H. (2019). Three perspectives on relational values of nature. Sustainability Science 14(5), 1201-1212. DOI: 10.1007/s11625-019-00718-4.

[67] Švajda, J. \& Fenichel, E. P. (2011). Evaluation of Integrated Protected Area Management in Slovakian National Parks. Polish Journal of Environmental Studies 20(4), 1053-1060.

[68] Termorshuizen, J. W. \& Opdam, P. (2009). Landscape services as a bridge between landscape ecology and sustainable development. Landscape Ecology 24(8), 1037-1052. DOI: 10.1007/s10980-008-9314-8.

[69] Vačkár, D., Frélichová, J., Lorencová, E., Pártl, A., Harmáčková, Z. \& Loučková B. (2013). Metodologický rámec integrovaného hodnocení ekosystémových služeb v České republice. Praha: Czech Academy of Sciences. 
[70] Zanten, V. B. T., Verburg, P. H., Espinosa, M., Gomez-y-Paloma, S., Galimberti, G., Kantelhardt, J., Kapfer, M., Lefebvre, M., Manrique, R., Piorr, A., Raggi, M., Schaller, L., Targetti, S., Zasada, I. \& Viaggi, D. (2013). European agricultural landscapes, common agricultural policy and ecosystem services: a review. Agronomy for Sustainable Development 34(2), 309-325. DOI: 10.1007/s13593-013-0183-4.

[71] Vilček, J. (2014). Mapovanie a hodnotenie environmentálnych funkcií pol'nohospodárskych pôd Slovenska. Geografický časopis 66 (3), 287-304.

[72] Wang, Z., Mao, D., Li, L., Jia, M., Dong, Z., Miao, Z., Ren, C. \& Song, C. (2015). Quantifying changes in multiple ecosystem services during 1992-2012 in the Sanjiang Plain of China. Science of the Total Environmnent 514, 119-130. DOI: 10.1016/j.scitotenv.2015.01.007.

[73] Yang, Q., Liu, G., Casazza, M., Campbell, E. T., Giannetti, B. F. \& Brown, M. T. (2018). Development of a new framework for non-monetary accounting on ecosystem services valuation. Ecosystem Services 34, 37-54. DOI: 10.1016/j.ecoser.2018.09.006.

[74] Yang, Y., Zheng, H., Kong, L., Huang, B. \& Xu, W. (2019). Mapping ecosystem services bundles to detect high-and low-value ecosystem services areas for land use management. Journal of Cleaner Production 225, 11-17. DOI: 10.1016/j.jclepro.2019.03.242.

[75] Zhang, W., Ricketts, T. H., Kremen, C., Carney, K. \& Swinton, S. M. (2007). Ecosystem services and dis-services to agriculture. Ecological Economics 64(2), 253-260. DOI: 10.1016/j.ecolecon.2007.02.024.

Other sources

[76] Eurostat LUCAS 2012 survey (http://ec.europa.eu/eurostat/statisticsexplained/index.php/Land_cover_statistics).

[77] MEA (2005). Ecosystems and human well-being: synthesis. Island Press, Washington, DC.

[78] Methodical guideline of the Ministry of Industry and Trade of the Slovak Republic No. $1304 / 2010-630$.

[79] SNBS, 2013. https://www.minzp.sk/files/sekciaochranyprirodyakrajiny/dohovory/biodiverzita/narodna_strateg_ochr_biodiverz_2020.pdf. 